\title{
Development and validation a nursing care protocol with educational interventions for family caregivers of elderly people after stroke
}

\author{
Construção e validação de protocolo assistencial de enfermagem com intervenções educativas para \\ cuidadores familiares de idosos após Acidente Vascular Cerebral \\ Construcción y validación de un protocolo de asistencia de enfermería con intervenciones educativas \\ para personas mayores de carrera después de un Accidente Cerebrovascular
}

Naiana Oliveira dos Santos'
ORCID: 0000-0002-5439-2607

Mariane Lurdes Predebon" ORCID: 0000-0003-1085-3034

Carla Cristiane Becker Kottwitz Bierhals" ORCID: 0000-0002-6956-1549

Carolina Baltar Day"II ORCID: 0000-0002-5998-5735

Diani de Oliveira Machado ${ }^{\text {Iv }}$ ORCID: 0000-0001-6149-4073

Lisiane Manganelli Girardi Paskulin" ORCID: 0000-0003-1444-4086

Universidade Franciscana. Santa Maria Rio Grande do Sul, Brazil.

"Universidade Federal do Rio Grande do Sul. Porto Alegre Rio Grande do Sul, Brazil.

I'Hospital Nossa Senhora da Conceição Porto Alegre. Porto Alegre, Rio Grande do Sul, Brazil.

"Ninistério da Saúde. Brasília, Brazil.

How to cite this article: Santos NO, Predebon ML, Bierhals CCBK, Day CB, Machado DO, Paskulin LMG. Development and validation a nursing care protocol with educational interventions for

family caregivers of elderly people after stroke.

Rev Bras Enferm. 2020;73(Suppl 3):e20180894. doi: http://dx.doi.org/10.1590/0034-7167-2018-0894

Corresponding author:

Naiana Oliveira dos Santos

E-mail: naiaoliveira07@gmail.com

EDITOR IN CHIEF: Antonio José de Almeida Filho ASSOCIATE EDITOR: Alexandre Balsanelli

\section{ABSTRACT}

Objective: development and validation the content of a nursing care protocol with educational interventions for family caregivers of elderly people after stroke. Methods: a methodological study conducted in three stages: (1) protocol development through literature review; (2) pretest with multidisciplinary team, analyzed with literature articulation; (3) protocol validation by the Delphi Technique. Results: the protocol was structured in the following areas: Disease Guidelines; Emotional Support; Using the Health Care Network; Diet; Airways; Medications; Hygiene; Skin Care; Disposal; Dressing/Undressing; Positioning and Transfer; Fall Prevention. In the pretest, eight experts assessed protocol clarity and content. In validation, there were two rounds by the Delphi Technique. The validated protocol consisted of 12 domains, containing 42 items and 240 care guidelines. Conclusion: the protocol qualifies the transition of care after hospital discharge assisting nurses in home care practice.

Descriptors: Stroke; Aged; Caregivers; Validation Studies; Home Nursing.

\section{RESUMO}

Objetivo: construir e validar o conteúdo de um protocolo assistencial de enfermagem com intervenções educativas para cuidadores familiares de idosos após Acidente Vascular Cerebral. Métodos: estudo metodológico conduzido em três etapas: (1) construção do protocolo por meio de revisão da literatura; (2) pré-teste com equipe multiprofissional, analisado com articulação da literatura; (3) validação do protocolo pela Técnica Delphi. Resultados: o protocolo foi estruturado nos domínios: Orientações Sobre a Doença; Suporte Emocional; Utilização da Rede de Atenção à Saúde; Alimentação; Vias Aéreas; Medicações; Higiene; Cuidados com a Pele; Eliminações; Vestir/Despir; Posicionamento e Transferência; Prevenção de Quedas. No pré-teste, oito especialistas avaliaram a clareza e o conteúdo do protocolo. Na validação, houveram duas rodadas pela Técnica Delphi. O protocolo validado foi composto por 12 domínios contendo 42 itens e 240 orientações de cuidados. Conclusão: o protocolo qualifica a transição do cuidado após alta hospitalar auxiliando os enfermeiros na prática assistencial no domicílio.

Descritores: Acidente Cerebral Vascular; Idoso; Cuidadores; Estudos de Validação; Assistência Domiciliar.

\section{RESUMEN}

Objetivo: desarrollar y validar el contenido de un protocolo de atención de enfermería con intervenciones educativas para cuidadores familiares de personas mayores después de un accidente cerebrovascular. Métodos: estudio metodológico realizado en tres pasos: (1) construcción del protocolo mediante revisión de la literatura; (2) pretest con equipo multiprofesional, analizado con articulación bibliográfica; (3) validación del protocolo por la técnica Delphi. Resultados: wl protocolo fue estructurado en las siguientes áreas: Guías de Enfermedades; Apoyo Emocional; Uso de la Red de Atención Médica; Alimentación;Vías Respiratorias; Medicamentos; Higiene; Cuidado de laPpiel; Eliminaciones; Vestirse/Desvestirse; Posicionamiento y Transferencia; Prevención de Caídas. En la prueba preliminar, ocho expertos evaluaron la claridad y el contenido del protocolo. En la validación, hubo dos rondas por la Técnica Delphi. El protocolo validado consistió en 12 dominios, que contenían 42 ítems y 240 pautas de atención. Conclusión: el protocolo califica la transición de la atención después del alta hospitalaria, ayudando a las enfermeras en la práctica de atención domiciliaria de salud.

Descriptores: Accidente Cerebrovascular; Anciano; Cuidadores; Estudios de Validación; Atención Domiciliaria de Salud. 


\section{INTRODUCTION}

Elderly patients who are survivors of stroke have limitations that interfere with the performance of Activities of Daily Living $(A D L)$, requiring assistance for self-care. In general, after hospital discharge, the dependent elderly care is provided by the family, also leading to a change in the roles in the family nucleus. Often the family caregiver suddenly provides care without prior training ${ }^{(1-2)}$. It is understood that this family caregiver is an informal caregiver who has the responsibility of assisting the elderly at home in tasks for which the elderly have temporary or definitive functional disability. He/she could be a family member, friend, neighbor, or other community member providing such care without employment.

The learning of the caregiver of an elderly person after stroke begins, at first, through guidance made by multidisciplinary teams during hospitalization. In the return to the community, the service is provided by primary care or by home care services, when existing and according to the needs of the elderly. In Brazil, home care $(\mathrm{HC})$ is provided for primary and home care services according to the complexity of care to users ${ }^{(3)}$.

The modalities of $\mathrm{HC}$ range from $\mathrm{HC}$ provided by the primary care team to clinically stable users with less need for health resources and unable to go to the Health Unit ( $\mathrm{HC} 1$ ) and users with health problems that need continuous monitoring ( $\mathrm{HC} 2$ ). Also, users who need more complex care, such as the use of oxygen therapy, ventilatory support, peritoneal dialysis and paracentesis $(\mathrm{HC} 3)^{(3)}$.

Proper preparation of the caregiver is part of care transition actions in the three points of care of the health network (hospital, $\mathrm{HC}$, and primary care services). In this context, the nurse, in most cases, is the professional who is dedicated to performing educational interventions ${ }^{(4)}$. Following stroke, appropriate transfer of care from hospital to home and follow-up of patients at home can positively interfere with reduction of adverse effects, risk for hospital readmission and use of emergency services ${ }^{(5-6)}$. However, actions for an effective care transition are not a reality in most Brazilian institutions, especially with regard to caregiver education for HC. Specifically, in caring for the caregiver and the elderly stroke survivor, the nurse is the professional with educative skills to enable them ${ }^{(7)}$.

The use of protocols with systematic guidelines that assist nurses in interventions in community settings is a practice established in developed countries. The protocols frequently used and presented in the literature are the Resident Assessment Instrument (Inter-RAI) and the Outcomes and Assessment Information Set (OASIS), not yet translated or validated for use in Brazil. These devices are not specific for guidance of family caregivers of elderly people after stroke, they have been used to assess people with chronic needs and post-acute care using multidimensional assessment ${ }^{(8-9)}$.

In Brazil, to date, there are no conventionally defined protocols for $\mathrm{HC}$ management. Some existing programs propose to assess only the health care needs of users or the organization of services, but do not systematize care or suggest interventions such as international protocols ${ }^{(10)}$.

A protocol directs the actions of professionals for disease prevention or health recovery/rehabilitation. Such actions include assessments, diagnoses, care and treatment performed by the nursing staff through educational, emotional, social and/ or pharmacological interventions ${ }^{(11)}$. The use of educational protocols, as well as their development and validation, has been performed in the nursing care practice, especially in a hospital context directed to patients before and after bariatric surgery ${ }^{(12)}$, under oral anticoagulants ${ }^{(13)}$, with ventricular assist device ${ }^{(14)}$.

However, so far, there are no educational protocols directed at caregivers of elderly people after stroke at home. At home, there is an experience report about development an educational folder for caregivers containing guidelines for patient care with stroke disabilities, about risk of infection, physical mobility and impaired ambulation, difficulties with self-care and risk of falls ${ }^{(15)}$.

The use of a specific protocol qualifies nursing care, supports the transition of care in managing the care network to the target population in the home setting and contributes to the systematization of care and future multidimensional protocols. In addition, it can indirectly assist in reducing readmission rates and caregiver burden.

\section{OBJECTIVE}

To build and validate the content of a nursing care protocol with educational interventions for family caregivers of elderly people after stroke.

\section{METHODS}

\section{Ethical aspects}

The project was approved by the Research Ethics Committee of the Hospital de Clínicas de Porto Alegre (HCPA). All participants agreed to integrate the research by means of Free and Informed Consent.

\section{Design, place of study and period}

This is a methodological research ${ }^{(16)}$ developed in three sequential stages in 2016 and 2017. The first stage deals with educational intervention protocol development, the second with pretest and the third with validation.

\section{Study protocol}

In the first stage, the definition of the protocol domains was performed from the literature review on the subject under study to determine the nature and format of the information to be included. For this, a survey was conducted in the MEDLINE and CINAHL databases via EBSCO, using the search strategy:"guidelines" associated through the Boolean operator and "family caregivers". It was also used the Guia Prático do Cuidador (freely translated as Caregiver's Practical Guide) ${ }^{(17)}$, the educational manuals of the Health Education collection ${ }^{(18)}$ and the research of the research group that assessed the needs of the family caregiver to support the elderly linked to a Home Care Program ${ }^{(19)}$. The Taxonomy of Nursing Interventions Classification (NIC) was also used and a pilot study conducted in Portugal aimed to describe an intervention based on the skills of informal caregivers when caring for older people after a stroke at home (InCARE) ${ }^{(6)}$. From the information obtained at this stage, the main researcher discussed with the other members of the research group about the most relevant domains to compose the preliminary version of the protocol. 
In the second stage, the protocol was sent by e-mail to eight professionals from a multidisciplinary team of a public university hospital in southern Brazil, who work in the care transition from hospital to home. These professionals were intentionally chosen in order to perform a pretest to assess the clarity and understanding of the protocol content.

Stage three included the validation of the educational intervention protocol through Delphi Technique. Validation was guided by the theoretical framework of content validity ${ }^{(20)}$, which describes how the percentage of experts who agreed on the content of the material built should be measured. First, a survey of these experts was conducted through the Lattes Platform of the CNPq (Brazilian National Council for Scientific and Technological Development - Conselho Nacional de Desenvolvimento Científico e Tecnológico) portal. The search by subject (keywords: "home care" AND "nursing") was started in the simple search option. For contact with experts, the email address available on the Platform was used.

Inclusion criteria were nurses with experience of at least six months in $\mathrm{HC}$ and/or researchers with publications on the subject. Experts who did not respond within 10 days after the first contact were excluded. The educational intervention protocol was delivered to these experts to verify the level of agreement between them for each of the domains with their respective items and guidelines of the care protocol. Delphi technique operationalization was performed with the online Cognito forms platform, through two rounds of questionnaires ${ }^{(21)}$.

Expert panel agreement was assessed by the Likert Scale for each item in each domain: 1) I strongly disagree; 2) I disagree; 3 ) I neither agree nor disagree; 4) I agree; 5) I strongly agree. The process was repeated until the minimum agreement level of $75 \%$ was reached by adding the items "I agree" and "I strongly agree"(22). Participants received feedback on the responses, and guidelines were reformulated or new suggestions were included between each round, according to the experts' suggestions.

\section{Analysis of results, and statistics}

In the first and second stages of this study, the analysis was performed through articulation with the literature on the subject under study. In the third stage, the data received statistical treatment ${ }^{(21)}$. The mean, median and standard deviation for the answers were calculated. The criterion for expert consensus assessment was the judgment of convergent opinions with a minimum favorable level of $75 \%$ resulting from the sum of the "I agree" and "I strongly agree" ( 4 and 5 on the Likert scale) answers applied to the evaluators.

\section{RESULTS}

In the first stage, protocol development, through literature review, the definition of the protocol domains was based on the following criteria: care activities often performed by the family caregiver; activities that caregivers need guidance and support from health professionals to perform them properly considering specificities of the age group; aspects related both to the elderly affected by stroke and to their caregiver. It is noteworthy that the domains included both self-care activities, as well as aspects related to health care network, emotional support, and disease guidelines.

In order to make the complete protocol for information and meet the demands from the elderly with less complexity of care after stroke to those more dependent, we chose to divide the domains into items with their respective care guidelines. The preliminary version of the protocol comprised 12 domains: Stroke Guidelines; Emotional Support; Using the Health Care Network; Diet; Airways; Medications; Hygiene; Skin Care; Disposals; Dressing/Undressing; Positioning and Transfer; Falls. The build version of the first protocol step is illustrated in Figure 1.

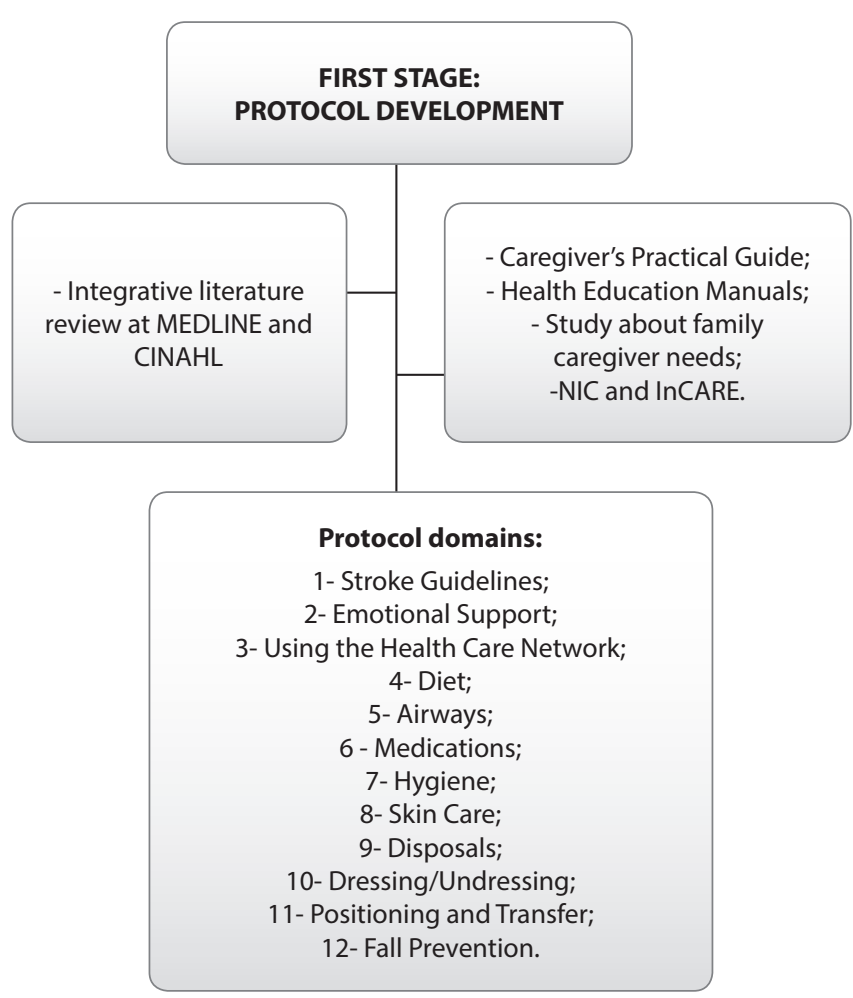

Note: NIC = Nursing Interventions Classification; InCARE = Intervention in informal caregivers who take care of older people after a stroke.

Figure 1 - Results of the first phase of the protocol development study, Brazil, 2017

In the pretest, eight experts from the multidisciplinary team participated (Figure 2). The 12 domains of the protocol were presented to experts by the researcher. Each one was asked to choose which domains felt most competent to assess the guidelines as an expert. Additions and/or modifications to domains were suggested: Stroke Guidelines; Emotional Support; Using the Health Care Network; Diet; Airways; Medications; Hygiene; Skin Care; Disposals; Positioning and transfer. No changes suggested in the domains: Dressing/Undressing and Fall Prevention.

In the third stage validation of the protocol by Delphi Technique, 320 nurses were invited to participate in the Delphi Technique. Of these, 42 experts accepted and composed the first round of protocol assessment. In the first round, the 12 domains were presented with their respective items and guidelines. Of these, three guidelines in the Using the Health Care Network domain, one in the domain Diet and one in the Disposal domain did not 
reach $75 \%$ of agreement. It was suggested to complement existing guidelines in the Stroke Guidelines, Emotional Support, Diet, Medications domains.

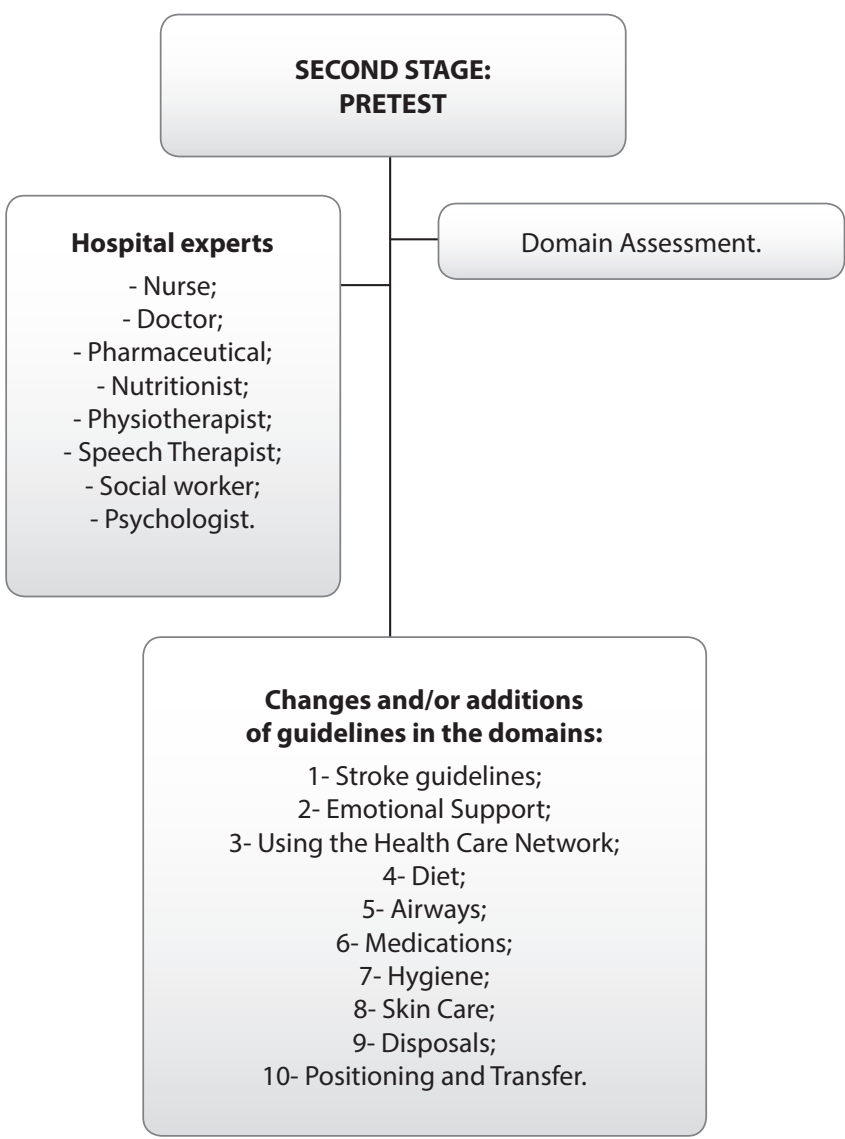

Figure 2 - Results of the second phase of the pretest study, Brazil, 2017

Experts also recommended including guidance in the following domains: Stroke Guidelines; Emotional Support; Using the Health Care Network; Diet; Skin Care; Disposals; Medications. In addition, inclusion of new items in the Airway domain (cleaning of the aspirator and suction cup and nasopharyngeal and oropharyngeal aspiration) and in the Hygiene (foot hygiene) domain was also recommended).

Thus, the domains, items and guidelines for which additions were suggested or that had recommendations for complementation with change of care guideline were returned to the second round, even having reached the minimum agreement of $75 \%$. In the second and final round of the Delphi Technique, protocol domain guidance was sent to the 42 first round respondents. The return of 36 participants (85.7\%) was obtained, reaching an abstention rate of $14.3 \%$. The results of the validation stages by Delphi Technique are presented in Figure 3.

Chart 1 presents the domains and their respective guidance items of the final version of the protocol. In short, the protocol was structured into 12 domains, divided into 42 items that include over 240 care guidelines $^{(23)}$. Item 1 of the Medications domain is presented in Chart 2 with the respective guidelines. Due to the extension of the protocol, we chose to present this domain as one of the care activities most performed by caregivers at home.

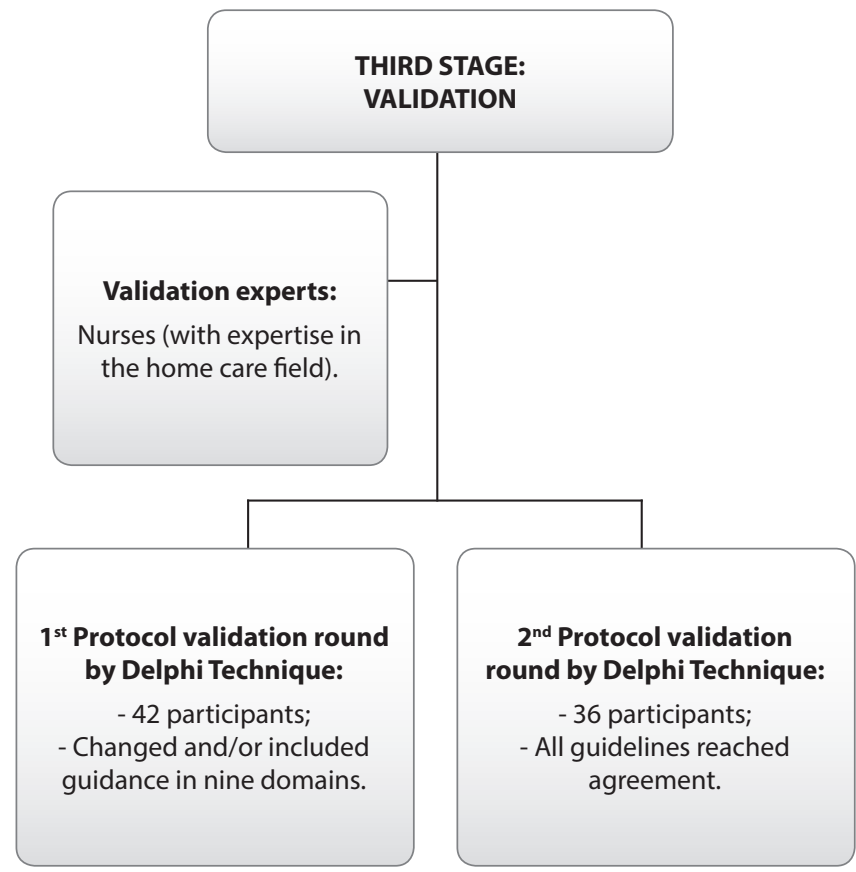

Figure 3 - Results of the third stage of the validation study, Brazil, 2017

Chart 1 - Domains and items of the final version of the Educational Interventions Protocol for Family Caregivers of Elderly People after Stroke, Brazil, 2017

\begin{tabular}{|l|l|}
\hline \multicolumn{2}{|c|}{ Protocol of Educational Interventions for Family Caregivers of } \\
Elderly People after Stroke
\end{tabular}


Chart 1 (concluded)

\begin{tabular}{|l|l|}
\hline \multicolumn{2}{|c|}{ Protocol of Educational Interventions for Family Caregivers of } \\
Elderly People after Stroke
\end{tabular}

Chart 2 - Domain 6: Medications, general medication guidelines item, Brazil, 2017

\section{DOMAIN 6: MEDICATIONS ITEM: GENERAL MEDICATION GUIDELINES}

1. Separate medications into bags labeled with medication names and times of administration and do not unpack them in their original packaging to control their expiration date and to avoid mixing.

2. Do not use expired medications. Keep medicines in appropriate places away from heat and moisture. Those in need of refrigeration should be stored in the refrigerator (medicines should not be stored near the freezer and refrigerator door). E.g., insulin.

3. Dressing materials and medicines such as ointments, gauze, bandages, tape and saline should be stored in a box with a lid, separated from other medicines.

4. Misting materials should be stored in a plastic box with a lid and always dry.

5. Keep the latest prescription always close to where your medications are stored for easy reference. If in doubt about how to take your medication, ask for help from a family member/caregiver or health care team.

6. Do not modify your prescription by reducing or increasing medication doses, or stop taking a continuous medication yourself without the advice of a qualified professional.

7. Turn on the light whenever you are preparing or giving medication to avoid changes.

To be continued
Chart 2 (concluded)

DOMAIN 6: MEDICATIONS

ITEM: GENERAL MEDICATION GUIDELINES

8. Tell the health care team if the elderly person often uses natural teas, herbal and homeopathic formulas. Plants can interfere with the action of some medicines by increasing or decreasing the desired effect (E.g., Ginseng, Ginkgo Biloba).

9. Always read the name of the medicine before giving it.

10. Do not use medicines on your own or as directed by others, as trying to help may worsen your health.

11. Use a guideline with the name and time of the medications to be administered. To help you remember your medication schedules, adjust your intake schedules with daily activities such as brushing your teeth, mealtimes, or bedtime.

12. If you experience any of these symptoms during treatment: nausea, vomiting, skin changes, changes in your bowel habits and poor appetite, be sure to inform your doctor.

\section{DISCUSSION}

Development evidence-based protocols that support educational interventions by nurses is critical to ensuring quality care for the user and family. The theoretical content that structures this protocol is based on the best clinical evidence being readapted, after validation of its content by experts, in which the mixture of views, cultures and scientific knowledge. National and international studies on protocol development ${ }^{(24-26)}$ were also based on existing best practice.

The professionals who participated in the pretest contributed to the improvement of the instrument with a more specialized look and to integrate, align and qualify the transition from care to home. In addition, they worked in a referral hospital for stroke patients, with experience of planning discharge with the patient and family caregiver. On the other hand, validation through Delphi Technique with nurse experts in $\mathrm{HC}$ provided a closer look at the $\mathrm{HC}$ context, ensuring that the guidelines were directed to the needs of users and family members in the reality they are inserted. Corroborating the results found in the validation phase, other studies ${ }^{(27-28)}$ also suggest the performance of the pretest in order to assess the clarity and understanding of the information present in the protocol.

Similar to the present study, other investigations ${ }^{(29-30)}$ used the content validation process by Delphi technique, which consists of making rounds until obtaining expert agreement. Similar results were identified in other studies that showed that materials were validated after two to four rounds using the Delphi technique ${ }^{(31-32)}$.

The nurses made important changes in the content of the material. Regarding the guidelines of each protocol item, changes were suggested both in the content and in the reformulation of some sentences. Suggestions for substitution and explanation of terms considered inappropriate and confusing, as well as the addition of relevant information were necessary, as the guidance provided by health professionals must be accurate and of quality.

In the Stroke Guidelines domain, experts suggested that the guidelines consist of a language more accessible to caregivers. Communication between health professionals, caregivers and patients is crucial, particularly when discussing the needs of care 
and information, especially for those in whom this information is $n^{(33)}$. Still in this domain, experts stressed that it is necessary to clarify what needs to be done when the elderly are presenting a new stroke, as well as the importance of noting the time when the first symptoms appeared. This information enables effective care consistent with patient needs. In this way, stroke sequelae are minimized and it is possible to guarantee a better quality of life for this population affected by the disease ${ }^{(34)}$.

In the Emotional Support domain, caregiver support guidance has been included to encourage caregivers to share responsibilities, debt tasks with other family members and not neglect their physical and emotional health. A systematic review study that sought to describe and explain the experiences of stroke survivors and their informal caregivers showed that in the face of a daily accumulation of activities, lack of support from other family members and their own health services, the caregiver prioritizes care for the dependent relative to the detriment of their self-care ${ }^{(35)}$. In addition, the formal support network is crucial for an effective transition to the caregiver role, as it provides health information, professional support and community support networks ${ }^{(36)}$.

In the Using the Health Care Network domain, experts highlighted the importance of approaching the available services with family caregivers and patients and how the access to the health care network is given. This information is indispensable for the qualification and continuity of health care and optimization of resources available to the community. It is also known that material resources and financial support to support families caring for dependent older people is still restricted in Brazil. On the other hand, users are often unaware of what is available. This guidance can help alleviate and remedy families' difficulties with regard to material, financial and health support ${ }^{(37-38)}$.

The Medications domain was the one that got the most suggestions from experts. Studies on the transition of care and on hospital readmission have identified that this aspect deserves to be addressed with greater emphasis. The causes of readmissions are medication reconciliation, inability to perform self-care and patients' lack of knowledge about their disease ${ }^{(5-39)}$. Thus, information about the use, administration, storage, care and adverse effects of medications are important to be clarified to users and caregivers.

The changes that occur in the elderly after stroke reflect on their functional capacity, making it difficult or impossible to perform routine tasks, such as ADL. The Dressing/Undressing domain is related to the results found with the caregiver's unpreparedness to perform care activities such as bathing and dressing, which may predispose the appearance of low back pain and back problems ${ }^{(40)}$.

Regarding the guideline of the Positioning and Transfer domain, the skills to perform these care activities are related to the use of appropriate techniques for their execution and is strictly related to the degree of patient dependence. Neurological deficits caused by stroke alter the muscle control and body sensitivity of the patient, thus needing to maintain a correct anatomical positioning ${ }^{(41-42)}$. Nursing guidance to the caregiver regarding the correct use of cushions, pillows and pillows can help reduce the risk of developing pressure injuries and provide patient well-being after stroke.

Protocol guidelines that did not reach consensus in the first round of the Delphi Technique were re-presented with expert suggestions, and all gained consensus in the second round. This data allows us to state that the results are reliable and that the proposed protocol can be implemented by nurses, as it provides information for conducting educational interventions with elderly caregivers. They have knowledge so that they can structure and plan actions aimed at the education of family caregivers, aiming to assist them in their care activities, allowing them to develop HC skills.

\section{Study limitations}

Difficulties were identified in the Delphi technique validation stage. It is configured in a data collection tool that does not allow face-to-face contact with experts. It requires dedication and time to assess the protocol, delayed return of experts on time, and low adherence rates from experts.

\section{Contributions to nursing, health or public policy}

This research presents advances in nursing knowledge from a methodological and care perspective, by developing a professional support instrument in a systematic way. The protocol can be considered as a technology to nursing care in $\mathrm{HC}$, as the transition of care. In addition, it proposes educational interventions based on theoretical frameworks on the subject and expert opinion in an integrated perspective, going beyond the need for assessment of the elderly with stroke and their family caregivers. For the research, it contributes to future investigations through intervention studies using the protocol.

\section{CONCLUSION}

The development and validation educational protocol consists of 12 care domains, divided into 42 items that include more than 240 care guidelines directed to the use of nurses with family caregivers of elderly people after stroke at home.

The protocol development stage through literature review was fundamental to determine the educational interventions that should be directed to family caregivers of elderly people after stroke. In addition, existing best practices related to the theme under study made it possible to elaborate the operational and constitutive definitions of the protocol through domains, items and guidelines. The pretest with a multidisciplinary team significantly contributed to the improvement of the instrument's items and guidelines, as the team works in a referral hospital for stroke patients, having the experience of planning discharge with the patient and their family caregiver. Validation by Delphi Technique took place in two rounds and was assessed by nurses from all over the country. The importance of these professionals to have experience in $\mathrm{HC}$ is highlighted, which ensures that the guidelines are directed to the needs of users and their families and the context in which they are inserted.

The present study provides evidence for nursing education, for the discussion of new health practices and policies directed to care assistance to the elderly population affected by stroke and their family caregivers. It is presented as a practical tool that provides subsidies to nursing professionals in education and HC, with standardized guidelines specific to this population. Thus, it 
qualifies the transition of care and $\mathrm{HC}$, expanding health care actions of this population, as well as the structuring of a support network.

\section{FUNDING}

The present study received support from the following institutions: Higher Education Personnel Improvement Coordination (CAPES - Coordenação de Aperfeiçoamento de Pessoal de Nível
Superior), and Research and Events Incentive Fund of Hospital de Clinicas de Porto Alegre (FIPE (Fundo de Incentivo à Pesquisa e Eventos)/HCPA).

\section{ACKNOWLEDGMENTS}

A special thanks to CAPES for the assignment of Graduate scholarship, doctorate level and to FIPE/HCPA.

\section{REFERENCES}

1. Rodrigues RAP, Marques S, Kusumota L, Santos EB, Fhon JRS, Fabrício-Wehbe SCC. Transition of care for the elderly after cerebrovascular accidents: from hospital to the home. Rev Latino-Am Enfermagem. 2013; 21(Spec):216-24. doi: 10.1590/S0104-11692013000700027

2. Gratão ACM, Talmelli LFS, Figueiredo LC, Rosset I, Freitas CP, Rodrigues RAP. Functional dependency of older individuals and caregiver burden. Rev Esc Enferm USP. 2013;47(1):137-44. doi: 10.1590/S0080-62342013000100017

3. Ministério da Saúde (BR). Portaria № 825 de 25 de abril de 2016. Redefine a Atenção Domiciliar no âmbito do Sistema Único de Saúde (SUS) e atualiza as equipes habilitadas [Internet]. Brasília: Ministério da Saúde; 2016 [cited 2019 Aug 14]. Available from: http://bvsms.saude.gov. br/bvs/saudelegis/gm/2016/prt0825_25_04_2016.html

4. Pereira RA, Santos EB, Fhon JRS, Marques S, Rodrigues RAP. Burden on caregivers of elderly victims of cerebrovascular accident. Rev EsC Enferm USP.2013;47(1):185-92. doi: 10.1590/S0080-62342013000100023

5. Guerrero KS, Puls SE, Andrew DA. Transition of care and the impact on the environment of care. J Nurs Educ Pract. 2014; 4(6):30-6. doi: 10.5430/jnep.v4n6p30

6. Araújo O, Lage I, Cabrita J, Teixeira L. Intervention in informal caregivers who take care of older people after a stroke (InCARE): study protocol for a randomised trial. J Adv Nurs. 2015;71(10):2435-43. doi: 10.1111/jan.12697

7. Silva RCA, Monteiro GL, Santos AG. Nurses' role in the education of caregivers of patients with stroke. Rev Atenção Saúde. 2015; 13(45):11420. doi: $10.13037 /$ rbcs.vol13n45.3114

8. InterRAI Organization. Resident Assesment Instrument (Inter-Rai) [Internet]. Ann Arbor: InterRAl Organization; 2018[cited 2018 Feb 20]. Available from: http://www.interrai.org

9. Centers for Medicare \& Medicaid Services. Outcome and Assessment Information Set (OASIS) [Internet]. Baltimore: Centers for Medicare \& Medicaid Services; 2012[cited 2018 Feb 20]. Available from: https://www.cms.gov/Medicare/Quality-Initiatives-Patient-AssessmentInstruments/OASIS/index.html

10. Ministério da Saúde (BR). Secretaria de Atenção à Saúde. Caderno de atenção domiciliar [Internet]. Brasília: Ministério da Saúde; 2013[cited 2018 Feb 20]. Available from: http://189.28.128.100/dab/docs/publicacoes/geral/cad_vol1.pdf

11. Lopes CT, Amorim AF, Nishi FA, Shimoda GT, Jensen R, Pimenta CAM. Guia para construção de protocolos assistenciais de enfermagem [Internet]. São Paulo: COREN-SP; 2015[cited 2018 Feb 20]. Available from: http://portal.coren-sp.gov.br/sites/default/files/Protocolo-web.pdf

12. Felix LG, Soares MJGO, Nóbrega MML. Nursing care protocol to the patient before and after bariatric surgery. Rev Bras Enferm. 2012;65(1):83-91. doi: 10.1590/S0034-71672012000100012

13. Pelegrino FMP, Bolela F, Corbi ISA, Carvalho ARS, Dantas RAS. Educational Protocol for Patients on Oral Anticoagulant Therapy: Construction and Validation. Texto Contexto Enferm. 2014;23(3):799-806. doi: 10.1590/0104-07072014001440013

14. Machado RC, Gironés $P$, Souza AR, Moreira RSL, von Jakitsch CB, Branco JNR. Nursing care protocol for patients with a ventricular assist device. Rev Bras Enferm. 2017;70(2):335-41. doi: 10.1590/0034-7167-2016-0363

15. Saldan GG, Figueiredo FSF, Misawa F, Rêgo AS, Salci MA, Radovanovic CAT. Construction of educational technology for home care after encephalic vascular accident: case report. Rev Enferm UFPE. 2017;11(4):1784-93. doi: 10.5205/reuol.9763-85423-1-SM.1104201729

16. Polit DF, Beck CT. Fundamentos de pesquisa em enfermagem: avaliação de evidências para a prática da enfermagem. $7^{a}$ ed. Porto Alegre: Artmed; 2011.

17. Ministério da Saúde (BR). Secretaria de Atenção à Saúde. Guia prático do cuidador [Internet]. Brasília: Ministério da Saúde; 2008 [cited 2018 Feb 20]. Available from: http://bvsms.saude.gov.br/bvs/ publicacoes/guia_pratico_cuidador.pdf

18. Hospital de Clínicas de Porto Alegre (HCPA). Educação em Saúde [Internet]. Porto Alegre: Hospital de Clínicas de Porto Alegre; 2016[cited 2018 Feb 20]. Available from: https://www.hcpa.edu.br/area-do-paciente-apresentacao/area-do-paciente-sua-saude/ area-do-paciente-sua-saude-educacao-em-saude

19. Bierhals CCBK, Santos NO, Fengler FL, Raubustt KD, Forbes DA, Paskulin LMG. Needs of family caregivers um older adults care at home. Rev Latino-Am Enfermagem. 2017;25:e2870. doi: 10.1590/1518-8345.1511.2870 
20. Dalmoro M, Vieira KM. Dilemmas of the type likert scales construction: does the number of items and the disposition influence results? Rev Gestão Org [Internet]. 2013[cited 2018 Jan 17];6(3):161-74. Available from: https://bell.unochapeco.edu.br/revistas/index.php/rgo/article/ viewFile/1386/1184

21. Scarparo AF, Laus AM, Azevedo ALCS, Freitas MRI, Gabriel CS, Chaves LDP. Reflections on the use of delphi technique in research in nursing. Rev. RENE [Internet]. 2012[cited 2018 Jan 17];13(1):242-51. Available from: http://www.periodicos.ufc.br/rene/article/view/3803

22. Hsu CC, Sandford BA. The Delphi Technique: making sense of consensus. Pratical Assessment, Research \& Evaluation [Internet]. 2007[cited 2018 Jan 17];12(10). Available from: http://pareonline.net/getvn.asp? $=12 \& n=10$

23. Santos NO. Construct and validate of protocol of educational intervention at home for caregivers of older adults post stroke [Tese] [Internet]. Porto Alegre: Universidade Federal do Rio Grande do Sul; 2017 [cited 2018 Feb 20]. Available from: http://www.lume.ufrgs.br/ handle/10183/158249

24. Lima ACMACC, Bezerra KC, Sousa DMN, Rocha JF, Oriá MOB. Construção e Validação de cartilha para prevenção da transmissão vertical do HIV. Acta Paul Enferm. 2017;30(2):181-9. doi: 10.1590/1982-0194201700028

25. Cordeiro LI, Lopes TO, Lira LEA, Feitoza SMS, Bessa MEP, Pereira MLD, et al. Validation of educational booklet for HIV/Aids prevention in older adults. Rev Bras Enferm. 2017;70(4):775-82. doi: 10.1590/0034-7167-2017-0145

26. Soong C, Daub S, Lee J, Majewski C, Musing E, Nord P, et al. Development of a Checklist of Safe Discharge Practices for Hospital Patients. J Hosp Med. 2013;8(8):444-9. doi: 10.1002/jhm.2032

27. Cardoso LRA, Abiko AK, Haga HCR, Inouye KP, Gonçalves OM. Prospecção de futuro e método Delphi: uma aplicação para a cadeia produtiva. Ambiente Construído[Internet]. 2005[cited 2019 Aug 14];5(3):63-78. Available from: https://seer.ufrgs.br/ambienteconstruido/ article/view/3650

28. Martins GA. Sobre Confiabilidade e validade. Rev Bras Ges Neg[Internet]. 2006[cited 2019 Aug 14];8(20):1-12. Available from: http://www. redalyc.org/articulo.oa?id=94782002

29. Maciel BS, Barros ALBL, Lopes JL. Elaboration and validation of an information manual for cardiac catheterization. Acta Paul Enferm. 2016;29(6):633-42. doi: 10.1590/1982-0194201600089

30. Santos EC, Oliveira ICM, Feijao AR. Validação de protocolo assistencial de enfermagem para pacientes em cuidados paliativos. Acta Paul Enferm. 2016; 29(4):363-73. doi: 10.1590/1982-0194201600051

31. Lopes JL, Nogueira-Martins LA, Barbosa DA, Barros AL. Development and validation of an informative booklet on bed bath. Acta Paul Enferm. 2013;26(6):554-60. doi: 10.1590/S0103-21002013000600008

32. Junges JR, Zóboli EL, Schaefer R, Nora CR, Basso M. Validation of the comprehensiveness of an instrument on ethical problems in primary care. Rev Gaúcha Enferm. 2014;35(2):148-56. doi: 10.1590/1983-1447.2014.01.39811

33. Pindus DM, Mullis R, Lim L, Wellwood I, Rundell AV, Abd Aziz NA, et al. Stroke survivors' and informal caregivers' experiences of primary care and community healthcare services: a systematic review and meta-ethnography. PLoS ONE. 2018;13(2):e0192533. doi: 10.1371/journal. pone.0192533

34. Lima ACMACC, Silva AL, Guerra DR, Barbosa IV, Bezerra KC, Oriá MOB. Nursing diagnoses in patients with cerebral vascular accident: an integrative review. Rev Bras Enferm. 2016;69(4):785-92. doi: 10.1590/0034-7167.2016690423i

35. Bergströma AL, Hanson E. An integrative review of information and communication technology based support interventions for careers of home dwelling older people. Technol Disabil. 2017;29(1-2):1-14. doi: 10.3233/TAD-160158

36. Tsai PC, Yip PK, Tai JJ, Lou MF. Needs of family caregivers of stroke patients: a longitudinal study of caregivers' perspectives. Patient Prefer Adherence. 2015;9:449-57. doi: 10.2147/PPA.S77713

37. Areosa SVC, Henz LF, Lawisch D, Areosa RC. Take care of oneself and other: study of elderly caregivers. Psicol Saúde Doenças. 2014;15(2):482 94. doi: $10.15309 / 14 p s d 150212$

38. Muniz EA, Freitas CASL, Oliveira EN, Lacerda MR. Overload degree of caregivers of elderly assisted at home by the Family Health Strategy. Saúde Debate. 2016;40(110):172-82. doi: 10.1590/0103-1104201611013

39. Shamji H, Baier RR, Gravenstein S, Gardner RL. Improving the quality of care and communication during patient transitions: best practices for urgent care centers. Jt Comm J Qual Patient Saf. 2014;40(7):319-24. doi: 10.1016/S1553-7250(14)40042-4

40. Yavo IS, Campos EMP. Caregiver and care: the subject and its relations in the context of household assistance. Rev Psicol: Teor Prát. 2016;18(1):20-32. doi: 10.15348/1980-6906/psicologia.v18n1p20-32

41. Vieira LA, Guedes MVC, Barros AA. Application of Glasgow, Braden and Ranking Scales in patients affected by cerebrovascular accident. J Nurs UFPE. 2016;10(5):4226-32. doi: 10.5205/reuol.9284-81146-1-SM.1005sup201608

42. Ayala ALM, Galende ACBPS, Stoeberl FR. Care in prevention of pressure ulcers of bedridden patients at home. Semina: Ciênc Biol Saúde. 2016;37(2):25-38. doi: 10.5433/1679-0367.2016v37n2p25 